\title{
PERANAN BIMBINGAN GURU DAN MOTIVASI BELAJAR DALAM RANGKA MENINGKATKAN PRESTASI BELAJAR PESERTA DIDIK SMA NEGERI 1 METRO TAHUN 2010
}

\author{
Sukirman \\ Universitas Muhammadiyah Metro
}

\begin{abstract}
Intisari: Tujuan penelitian ini untuk mengetahui dan meningkatkan peranan bimbingan guru dalam memberikan motivasi belajar demi meningkatkan prestasi belajar peserta didik SMA Negeri 1 Metro tahun pelajaran 2010/2011. Penelitian ini merupakan penelitian kuantitatif dalam bentuk korelasional dengan menggunakan metode survey dan dokumentasi. Populasi penelitiannya peserta didik SMA Negeri 1 Metro pada tahun pelajaran 2010/2011 yang berjumlah 590 orang. Sampel penelitian sebanyak 60 orang yang ditetapkan dengan teknik sampling, statifitikasi proporsional random sampling.

Instrumen yang digunakan dalam mengumpulkan data adalah 1) angket tertutup untuk mengumpulkan data bimbingan guru, dalam memotivasi belajar, dan 2) dokumentasi sekolah (nilai raport) untuk memperoleh data tentang prestasi belajar. Angket dilakukan uji validitas dan reliabilitas dengan menggunakan korelasi product moment dan rumus alpha. Teknik analisis data menggunakan korelasi sederhana dengan uji persyaratan normalitas dan homogenitas.

Hasil penelitian ini menjelaskan bahwa: terdapat hubungan positif (berperan) dan signifikan antara bimbingan guru dengan prestasi belajar, koefisien korelasi ry $\mathrm{x}_{1}=0,568$. Terdapat hubungannya erat antara motivasi belajar dengan prestasi belajar pada taraf signifikansi $1 \%$, korelasinya ry $x_{2}=$ sebesar 0.617. Menunjukkan bahwa bimbingan guru, dan motivasi belajar secara bersama-sama hubungannya erat dengan prestasi belajar pada taraf signifikansi $1 \%$, dengan nilai korelasinya $\mathrm{ry}_{1} \mathrm{x}_{2}=$ sebesar 0,647 .

Selanjutnya hasil penelitian diharapkan dapat menjadi masukan dan pendorong bagi guru, khususnya guru pembimbing untuk lebih memperhatikan kebutuhan peserta didik dalam proses pembelajaran, sehingga peserta didik mampu mengatasi kesulitan belajar yang dihadapi dan mendorong motivasi belajar dan mampu mengembangkan potensi yang dimiliki secara optimal.
\end{abstract}

Kata kunci: bimbingan guru, motivasi belajar dan prestasi belajar

\section{MUTU PENDIDIKAN}

Isu rendahnya mutu pendidikan atau rendahnya prestasi belajar peserta didik menjadikan terbitnya Peraturan Menteri Pendidikan Nasional (Permendiknas), seperti No.22 tentang Standar Isi dan No. 23 tentang Standar Kompetensi Lulusan untuk Satuan Pendidikan Dasar dan Menengah; Peraturan Pemerintah Republik Indonesia. No. 19 tentang Standar Nasional Pendidikan, selain adanya batas kelulusan setiap tahun pelajaran yang diupayakan terus meningkat.

Namun demikian peningkatan mutu pendidikan masih terkendala pada program pemerataan dan peningkatan kualitas pendidikan yang selama ini merupakan fokus pembinaan masih menjadi masalah 
yang paling menonjol dalam dunia pendidikan kita (Sidi, 2001); kualitas pendidikan di Indonesia masih rendah dan belum mampu memenuhi kebutuhan kompetensi peserta didik. Sebab utama dari hal tersebut antara lain belum meratanya pendidikan di tanah air baik secara kuantitas maupun kualitas, fasilitas sekolah yang belum memadai, tidak semua peserta didik memiliki buku-buku pelajaran, kualitas dan kompetensi guru yang masih harus ditingkatkan (PP. RI No.7 Tahun 2005); rendahnya daya saing (Yamin \& Ansori, 2008), dan rendahnya daya serap siswa (Trianto, 2007). Rendahnya mutu pendidikan merupakan wujud rendahnya prestasi belajar siswa yang dipengaruhi oleh (1) faktor-faktor yang berasal dari luar diri pelajar, dibedakan menjadi dua golongan, yaitu: faktor-faktor non sosial, dan faktor-faktor sosial. (2) faktor-faktor yang berasal dari dalam diri si pelajar, dan inipun dapat digolongkan menjadi dua golongan, faktor-faktor fisiologis, dan faktor-faktor psikologis (Suryabrata, 2006).

\section{Bimbingan Guru}

Menurut Prayitno (2004) bimbingan adalah proses pemberian bantuan yang dilakukan oleh orang yang ahli kepada seorang atau beberapa orang individu, baik anak-anak, remaja, maupun dewasa; agar orang yang dibimbing dapat mengembangkan kemampuan dirinya sendiri dan mandiri; dengan memanfaatkan kekuatan individu dan sarana yang ada dan dapat dikembangkan; berdasarkan norma-norma yang berlaku. Berdasarkan pengertian bimbingan tersebut, maka bimbingan adalah bantuan dari individu yang dewasa yang punya keahlian kepada individu yang belum dewasa, agar tercapai kedewasaan, melalui saling hubungan sesamanya, dan sesuai dengan norma-norma yang berlaku, sehingga mampu mengembangkan potensi dirinya secara maksimal.

Sebagaimana diketahui bahwa yang dimaksud bimbingan adalah bantuan, arahan, tuntunan, nasihat dari orang dewasa (guru atau orang tua) kepada individu yang belum dewasa (siswa atau anak). Bimbingan harus memenuhi syarat-syarat: (a) ada tujuan yang jelas untuk apa bantuan itu diberikan, (b) harus terencana, (c) berproses dan sistemtis, (d) menggunakan cara-cara atau pendekatan tertentu, (e) dilakukan oleh orang ahli, (f) dievaluasi untuk mengetahui hasil dari pemberian bantuan, tuntunan, atau pertolngan (Tohirin, 2007). Karena siswa sebagai individu yang belum dewasa dalam belajar, maka bimbingan guru sangat dibutuhkan agar siswa mudah mencapai tujuan belajar. Layanan pembelajaran dalam bimbingan belajar antara lain meliputi pengembangan motivasi, sikap, dan kebiasaan belajar yang baik, keterampilan belajar (Burhanudin 1995).

Bimbingan guru dalam hal ini difokuskan pada bimbingan belajar, yakni proses pemberian bantuan secara terus menerus dan sistematis oleh guru kepada siswa dalam rangka memecahkan kesulitankesulitan belajar yang dihadapi, sehingga siswa memiliki kemampuan untuk mencapai keberhasilan dalam belajar. Menurut Burhanudin (1995) meliputi kegiatan pengembangan motivasi, sikap, dan kebiasaan belajar yang baik, keterampilan belajar, program perbaikan dan pengayaan. Lebih lanjut Burhanudin menjelaskan kegiatan pada unsur (1) pengembangan motivasi, meliputi: memperjelas tujuan belajar, 
penyesuaian kemampuan, bakat, dan minat, suasana pembelajaran yang manantang, menyenangkan, pemberian penguatan, menciptakan suasana yang harmonis, menghindari suasana yang mengecewakan, melengkapi sumber belajar dan mempelajari hasil-hasil belajar. (2) pengembangan sikap dan kebiasaan belajar yang baik, mencakup: menemukan motif belajar yang tepat, memelihara kesehatan, mengatur waktu belajar yang baik, memilih tempat belajar, memanfaatkan sumber belajar yang sesuai, tidak segan untuk bertanya kepada guru atau teman, dan mengembangkan sikap positif terhadap semua materi pelajaran. (3) keterampilan belajar, mencakup: bagaimana membuat catatan, membuat ringkasan, melaksanakan diskusi, membuat laporan, cara memecahkan soal-soal, membaca atau cara belajar yang efektif dan efesien. (4) perbaikan dan pengayaan mencakup adanya kerjasama dalam memecahkan masalah belajar, baik yang mendapat kesulitan maupun yang ingin mengembangkan dari yang telah dikuasai.

Upaya untuk menarik perhatian dan meningkatkan persepsi siswa terhadap aktivitas guru, khususnya bimbingan belajar, maka guru perlu melakukan proses pembelajaran yang menarik, menyenangkan, dan dapat jadi contoh atau teladan bagi siswa. Sebagaimana dikemukakan oleh Karsidi (2007) bahwa peran guru terhadap murid-muridnya merupakan peran vital dari sekian peran yang harus dijalani, memberikan keteladanan, pengalaman serta ilmu pengetahuan kepada mereka. Tugas guru sebagai agen pembelajaran (learning agent), sebagai fasilitator, maupun motivator bagi siswa. Sebagai fasilitator, guru harus membantu siswa terhindar dari kesulitan belajar. Sebagai motivator, guru mampu membangkitkan motivasi belajar siswa. Guru memberikan kemudahan belajar (facilitate of learning) kepada seluruh siswa, agar mereka dapat belajar dalam suasana yang menyenangkan, gembira, penuh semangat, tidak cemas, dan berani mengemukakan pendapat secara terbuka (Mulyasa, 2007). Dalam hal ini peranan pendidik sangat besar dalam penentuan pandangan hidup si remaja. Karena itu kenalilah mereka, dan berilah mereka bimbingan (Suryabrata, 2006). Dengan memperoleh bimbingan mereka akan timbul sikap, perasaan, keberanian untuk mengambil suatu tindakan yang sesuai dengan norma yang berlaku.

Dalam proses belajar, bimbingan guru mampu mengatasi hambatan yang terjadi dalam kegiatan belajar, siswa mudah mencapai prestasi yang optimal. Secara lebih luas ditegaskan oleh Yusuf (2005) bahwa perkembangan optimal, perkembangan yang sesuai dengan potensi dan sistem nilai tentang kehidupan yang baik dan benar. Perkembangan optimal bukanlah semata-mata pencapaian tingkat kemampuan intelektual yang tinggi, yang ditandai dengan penguasaan pengetahuan dan keterampilan, melainkan suatu kondisi dinamik, dimana individu (1) mampu mengenal dan memahami diri, (2) berani menerima kenyataan diri secara obyektif, (3) mengarahkan diri sesuai dengan kemampuan, kesempatan, dan sistem nilai, dan (4) melakukan pilihan dan mengambil keputusan atas tanggung jawab sendiri.

\section{Motivasi Belajar}

Motivasi berasal dari kata motif, yang dapat diartikan sebagai kekuatan yang terdapat dalam diri individu, yang menyebabkan individu tersebut bertindak atau berbuat. Motivasi merupakan dorongan dan 
kekuatan dalam diri seseorang untuk melakukan tujuan tertentu yang ingin dicapainya (Uno, 2008). Tujuan yang dimaksud adalah sesuatu yang berada di luar diri manusia sehingga kegiatan manusia lebih terarah karena seseorang akan berusaha lebih semangat dan giat dalam berbuat sesuatu. Menurut Ahmadi (1998) motivasi diartikan sebagai keinginan untuk mencurahkan segala tenaga untuk mencapai tujuan yang diinginkan. Proses ini dirangsang oleh kemampuan unutk memenuhi kebutuhan individu. Artinya dengan didasari atas pemenuhan kebutuhannya, maka seseorang akan terpacu untuk melakukan sesuatu usaha sehingga pada akhirnya akan dapat memenuhi apa yang dibutuhkannya dan terwujud dalam bentuk perilaku tertentu. Pada kegiatan belajar, motivasi mempunyai peranan yang sangat menentukan. Kegiatan akan bermakna dan berhasil guna jika individu itu terdorong untuk belajar.keinginan ataupun usaha dari siswa yang tumbuh dari dalam dirinya merupakan tenaga yang mampu mendorong dan menggerakkan aktivitas untuk belajar yang lebih berdaya guna dan berhasil guna.

Motivasi dapat mempengaruhi seseorang dalam melakukan suatu kegiatan tertentu. Prinsip dalam belajar, motivasi sebagai pendorong tingkah laku mahasiswa/siswa kearah tujuan tertentu. Pendorong tersebut dapat diciptakan dosen atau guru dalam proses pembelajaran melalui metode intruksional. Bila metode yang dipakai menarik, maka mahasiswa/siswa akan termotifasi untuk belajar, ingin bekerja keras, dan berusaha menyelesaikan tugas hingga selesai.

Motivasi dapat dibedakan menjadi dua macam, yakni yang datang dari dalam diri individu (instrinsik), dan motivasi yang datang dari luar diri individu sebagai bentuk dorongan atau stimulus agar individu tergerak untuk melakukan sesuatu (ekstrinsik). Motivasi instrinsik berisi: (1) penyesuaian tugas dengan minat, (2) perencanaan yang penuh variasi, (3) umpan balik atas respon peserta didik, (4) kesempatan respon peserta didik yang aktif, dan (5) kesempatan peserta didik untuk menyesuaikan tugas pekerjaannya. Sedangkan motivasi ekstrinsik berisi: (1) penyesuaian tugas dengan minat, (2) perencanaan yang penuh variasi, (3) respon peserta didik, (4) kesempatan peserta didik yang aktif, (5) kesempatan peserta didik untuk menyesuaikan tugas pekerjaannya, dan (6) adanya kegiatan yang menarik dalam belajar (Uno, 2008).

Demikian halnya Walgito (2004) motivasi mempunyai tiga aspek: (1) keadaan terdorong dalam diri organisme (a drive state), yaitu kesiapan bergerak karena kebutuhan, misalnya kebutuhan jasmani, karena keadaan lingkungan, atau karena keadaan mental seperti berpikir, dan ingatan; (2) perilaku yang timbul dan terarah karena keadaan ini; dan (3) goal atau tujuan yang dituju oleh perilaku tersebut. Sedangkan Makmun (2003) menyatakan bahwa terdapat empat dorongan motivasi, yaitu motivasi keberhasilan, motivasi afiliasi, motivasi kompetensi, dan motivasi kekuasaan.

Berdasarkan pendapat tentang motivasi, maka dapat disimpulkan bahwa motivasi itu merupakan suatu dorongan yang timbul oleh adanya rangsangan dari dalam maupun dari luar, sehingga seseorang berkeinginan untuk melakukaan perubahan tingkah laku atau aktivitas tertentu yang sifatnya lebih baik 
dari keadaan sebelumnya. Adapun sasarannya: (1) mendorong seseorang untuk melakukan suatu aktivitas yan didasarkan atas pemenuhan kebutuhan/motivasi sebagai penggerak dari sikap kebutuhan yang akan dipenuhi, (2) menentukan arah tujuan yang hendak dicapai, dan (3) menentukan perbuatan yang harus dilakukan.

Motivasi dalam kegiatan belajar disebut sebagai motivasi belajar, yakni dorongan atau daya penggerak baik datang dari luar maupun yang datang dari dalam diri individu untuk melakukan suatu kegiatan belajar. Dimyati (2006) motivasi belajar merupakan kekuatan mental yang mendorong terjadinya proses belajar. Ada tiga komponen utama dalam motivasi (i) kebutuhan (ii) dorongan dan (iii) tujuan. Kebutuhan itu akan timbul manakala individu itu merasakan adanya ketidak seimbangan antara apa yang dimiliki dengan apa yang diharapkan. Winkel (2001) berpendapat motivasi belajar adalah keseluruhan daya penggerak psikis di dalam diri peserta didik yang menimbulkan kebiasaan belajar, menjamin kelangsungan belajar dan memberikan rah pada kegiatan belajar demi mencapai suatu tujuan. Jika siswa mempunyai keinginan untuk berhasil maka siswa tersebut akan tekun dan bersemangat dalam melakukan kegiatan belajar. Keinginan tersebut juga yang mendorong siswa untuk memeilih kegiatan yang penting dan relevan agar dapat memenuhi keinginan dan akan mengabaikan kegiatan yang tidak ada relevan dengan tujuannya.

Rendahnya motivasi belajar juga menyebabkan kurangnya semangat dan kegigihan belajar. Siswa yang kuat pengharapannya untuk sukses akan belajar lebih giat jika dibandingkan dengan siswa yang mencoba menghindari kegagalan. Pengharapan untuk sukses akan mendorong mereka untuk mencapai nilai yang lebih tinggi jika dibandingkan dengan siswa yang hanya pengharapannya asal lulus atau naik kelas.

Indikator motivasi belajar dapat diklasifikasikan sebagai berikut: (1) adanya hasrat dan keinginan berhasil, (2) adanya gorongan dan kebutuhan dalam belajar, (3) adanya harapan dan cita-cita masa depan, (4) adanya penghargaan dalam belajar, (5) adanya keinginan yang menarik dalam belajar, (6) adanya lingkungan belajar yang kondusif, sehingga memungkinkan seseorang peserta didik dapat belajar dengan baik (Uno, 2008).

Ada beberapa indikator yang harus diketahui dalam rangka memahami motivasi, Makmun (2003) dalam teori-teori motivasi yang dikutip dari http://akhmad sudrajat.wordpress.com/2008/02/06 mengemukakan bahwa untuk memahami motivasi individu dapat dilihat dari indikatornya, yakni: (1) durasi kegiatan; (2) frekuensi kegiatan; (3) persistensi pada kegiatan; (4) ketabahan, keuletan dan kemampuan dalam mengahadapi rintangan dan kesulitan; (5) devosi dan pengorbanan untuk mencapai tujuan; (6) tingkat aspirasi yang hendak dicapai dengan kegiatan yang dilakukan; (7) tingkat kualifikasi prestasi atau produk (out put) yang dicapai dari kegiatan yang dilakukan; (8) arah sikap terhadap sasaran kegiatan.

Berdasarkan beberapa pendapat tentang motivasi belajar, maka motivasi belajar adalah suatu daya dorong atau penggerak yang dapat menimbulkan aktivitas belajar, menjamin kelangsungan belajar, dan 
memberikan arah terhadap aktivitas belajar dalam rangka mencapai suatu tujuan belajar, yang dapat dilihat dari beberapa indikator: durasi kegiatan; frekuensi kegiatan; persistensi pada kegiatan; ketabahan, keuletan dan kemampuan dalam mengahadapi rintangan dan kesulitan; devosi dan pengorbanan untuk mencapai tujuan; tingkat aspirasi yang hendak dicapai dengan kegiatan yang dilakukan; tingkat kualifikasi prestasi atau produk (out put) yang dicapai dari kegiatan yang dilakukan; dan arah sikap terhadap sasaran kegiatan.

\section{Prestasi Belajar}

Prestasi belajar merupakan suatu kemampuan atau keberhasilan belajar individu terhadap materi pelajaran yang dipelajari, terlihat adanya perubahan, baik yang bersifat kognitif, afektip maupun psikomotor. Departemen Pendidikan dan Kebudayaan (1991) prestasi belajar adalah penguasaan pengetahuan atau keterampilan yang dikembangkan oleh mata pelajaran, lazimnya ditunjukkan dengan nilai tes atau angka nilai yang diberikan oleh guru. Sedangkan pengertian prestasi belajar menurut Gagne (dalam Sopah, 2000) adalah kemampuan yang dimiliki siswa sebagai akibat perbuatan belajar dan dapat diamati melalui penampilan siswa (learned's performance). Dick dan Reiser (dalam Sopah, 2000) mengatakan bahwa yang dimaksud dengan prestasi belajar adalah kemampuan-kemampuan yang dimiliki siswa sebagai hasil kegiatan pembelajaran. Selanjutnya mereka membagi keberhasilan atau prestasi belajar dalam empat macam, yaitu: (i) pengetahuan, (ii) keterampilan intelektual, (iii) keterampilan motorik, dan (iv) sikap. Tingkatan ranah kognitif dilakukan revisi oleh Anderson, dkk. (2001) yang dinyatakan bahwa Cognitive proses dimension meliputi: 1) remember, 2) understand, 3) apply, 4) analize, 5) evaluate, 6) create. Sehingga dengan demikian, menurut Anderson dkk, bahwa tingkatan yang tertinggi dalam ranah kofnitif bukan Evaluasi, tetapi kreasi (mencipta).

Berdasarkan tahapan kognitif Anderson, dalam teori belajar behavioristik, prestasi belajar merupakan suatu keluaran (respon) terhadap rangsangan (stimulus), yang datang dari dalam maupun dari luar berupa daya cipta individu. Stimulus yang datang dari luar, dalam proses pembelajaran sangat ditentukan oleh pemberian rangsangan yang diberikan oleh guru. Misalnya bimbingan dalam memahami konsep, bimbingan cara membaca kamus, membuat catatan, mengerjakan tugas, mengerjakan soal-soal yang sulit, menggunakan peralatan praktikum, atau pemberian hadiah atau pujian yang bersifat verbal, menunjukkan keberhasilan kerjanya kepada teman atau orang lain. Kesemuanya itu akan dapat memberikan dorongan kepada siswa untuk lebih giat belajar dan dapat meningkatkan respon atau prestasi belajar yang tinggi.

Untuk mengetahui keberhasilan siswa dalam proses belajar perlu dilakukan penilaian hasil belajar oleh pendidik. Dijelaskan lebih lanjut dalam Peraturan Pemerintah RI. No. 19 Tahun 2005, Bab X, Bagian kedua, pasal 64 bahwa penilaian itu dilakukan secara berkesinambungan untuk memantau proses, kemajuan, dan perbaikan hasil dalam bentuk ulangan harian, ulangan tengah semester, ulangan akhir semester, dan ulangan kenaikan kelas. 
Ukuran keberhasilan belajar dalam pengertian operasional adalah penguasaan suatu bahan ajar yang dinyatakan (TPK) tujuan pembelajaran khusus dan memiliki konstribusi bagi tujuan di atasnya (Fathurrohman, 2007). Sehingga dengan demikian sebenarnya ukuran keberhasilan/prestasi belajar siswa dalam mempelajari materi pelajaran adalah seberapa besar nilai atau skor yang diperoleh dari hasil mengerjakan soal atau tes dalam setiap tujuan pembelajaran yang telah ditentukan.

Prestasi belajar rendah ditandai dengan tidak tercapainya batas minimal ketuntasan belajar yang disepati bersama antara guru dan siswa pada aal proses pembelajaran. Kriteria ketuntasan belajar menurut Fathurrohman (2007) apabila 85\% dari jumlah siswa mencapai taraf keberhasilan optimal atau bahkan maksimal (mencapai 75\% penguasaan materi), maka proses belajar mengajar berikutnya dapat membahas pokok bahasan yang baru sehingga tak begitu penting untuk menyelenggarakan program perbaikan.

\section{Fungsi Motivasi dalam Belajar}

Menurut Uno (2008) beberapa peranan penting motivasi dalam belajar dan pembelajaran, antara lain dalam (a) menentukan hal-hal yang dapat dijadikan penguat belajar, (b) memperjelas tujuan belajar yang hendak dicapai, (c) menentukan ragam kendali terhadap rangsangan belajar, (d) menentukan ketekunan belajar. Motivasi berfungsi sebagai pendorong, pengarah, dan sekaligus sebagai penggerak perilaku seseorang untuk mencapai suatu tujuan. Motivasi erat kaitannya dengan masalah kebutuhan, jika seseorang memiliki suatu kebutuhan tertentu, maka meningkatlah motivasinya untuk meraih. Jika seorang peserta didik memiliki minat atau kebutuhan akan prestasi dalam belajar, maka ia akan tergerak perilakunya untuk mencapai tujuan tersebut.

Selain pendapat tersebut menurut Hamalik (dalam Fathurrohman, 2007) menyebutkan ada tiga fungsi motivasi: (1) mendorong manusia untuk berbuat, jadi sebagai penggerak atau motor yang melepaskan energi. Motivasi dalam hal ini merupakan langkah penggerak dari setiap kegiatan yang akan dikerjakan. (2) menentukan arah perbuatan, yakni kearah tujuan yang hendak dicapai. Dengan demikian motivasi dapat memberikan arah dan kegiatan yang harus dikerjakan sesuai dengan rumusan tujuannya. (3) menyeleksi perbuatan, yakni menentukan perbuatan-perbuatan mana yang harus dikerjakan yang serasi guna mencapai tujuan, dengan menyisihkan perbuatan-perbuatan yang tidak bermanfaat bagi tujuan tersebut.

Strategi yang dapat menumbuhkan motivasi belajar siswa yakni: 1) menjelaskan tujuan belajar ke peserta didik, pada permulaan proses pembelajaran seharusnya guru menyampaikan tujuan pembelajaran khusus yang akan dipelajari saat ini. Karena dengan mengetahui tujuan pembelajaran, peserta didik akan lebih terdorong, semangat dalam kegiatan belajar; 2) hadiah, hal merupakan suatu bentuk dorongan atau pemberian motivasi kepada siswa untuk lebih giat melakukan sesuatu kegiatan atau belajar, karena merasa apa yang dilakukan memperoleh perhatian dan penghargaan dari pihak lain, walaupun wujudnya tidak seberapa, namun dapat membuat siswa lebih giat belajar, untuk memperbaiki 
hasil prestasi yang telah dicapai sebelumnya. 3) saingan atau kompetisi, dalam hal ini guru perlu berusaha agar terjadi persaingan positif dalam belajar diantara peserta didik, berusaha untuk memperbaiki hasil prestasi belajar yang telah dicapai sebelumnya; 4) pujian, selayaknya siswa yang berhasil memperoleh pujian, walaupun hanya sekedar dengan ucapan "bagus, atau hebat, atau menakjubkan, atausekarang kamu benar-benar ada kemajuan," dan sebagainya; 5) hukuman, hal ini diberikan agar peserta didik yang melakukan kesalahan atau tidak tertib dalam mengerjakan tugas memperoleh efek jera dan tidak melakukan lagi, dan selanjutnya agar tumbuh motivasi belajarnya; 6) membangkitkan dorongan kepada peserta didik untuk belajar, caranya dengan memberikan perhatian maksimal kepada peserta didik, 7) membentuk kebiasaan belajar yang baik, 8) membantu kesulitan belajar peserta didik, baik secara individual maupun kelompok, 9) menggunakan metode yang bervariasi, hal ini agar peserta didik tidak terjadi kejenuhan karena cara guru menyampaikan materi bersifat monoton; 10) menggunakan media yang baik, serta harus sesuai dengan tujuan pembelajaran (Faturrohman, 2007).

Teknik-teknik yang dapat dilakukan dalam proses pembelajaran untuk menumbuhkan motivasi belajar ada dua puluh teknik, diuraikan lebih rinci oleh Uno (2008) yaitu: 1) pernyataan penghargaan secara verbal, 2) menggunakan nilai ulangan sebagai pemacu keberhasilan, 3) menimbulkan rasa ingin tahu, 4) memunculkan sesuatu yang tidak diduga oleh siswa, 5) menjadikan tahap dini dalam belajar mudah bagi siswa; hal ini mungkin memberikan hadiah bagi peserta didik pada tahap awal, agar menumbuhkan semangat belajar selanjutnya, 6) menggunakan materi yang dikenal siswa sebagai contoh dalam belajar, 7) gunakan kaitan yang unik dan tak terduga untuk menerapkan suatu konsep dan prinsip yang telah dipahami, 8) menuntut siswa untuk menggunakan hal-hal yang telah dipelajari sebelumnya, 9) menggunakan simulasi dan permainan, 10) memberikan kesempatan kepada siswa untuk memperlihatkan kemahirannya di depan umum, 11) mengurangi akibat yang tidak menyenangkan dan keterlibatan siswa dalam kegiatan belajar, 12) memahami iklim sosial dalam sekolah, 13) memanfaatkan kewibawaan guru secara tepat, 14) memperpadukan motif-motif yang kuat, 15) memperjelan tujuan belajar yang hendak dicapai, 16) merumuskan tujuan-tujuan sementara, 17) memberitahukan hasil kerja yang telah dicapai, 18) membuat suasana persaingan yang sehat diantara para siswa, 19) mengembangkan persaingan dengan diri sendiri; hal ini dapat dilakukan dengan memberikan tugas dalaam berbagai kegiatan yang harus dilakukan sendiri, dan 20) memberikan contoh yang positif.

Bagi siswa, jika memiliki motivasi belajar yang tinggi, maka akan mencapai kesuksesan dalam belajar, sebagaimana dikemukakan oleh Ahmadi (2004) bahwa motivasi sebagai faktor inner (batin) berfungsi menimbulkan, mendasari, mengarahkan perbuatan belajar. Setiap individu yang memiliki motivasi belajar tinggi akan mengalami kesuksesan dalam belajar maupun penyesuain diri. Motivasi belajar akan menentukan intensitas usaha belajar, jika motivasi belajar rendah atau menurun. Dalam penelitian ini yang dimaksud motivasi belajar adalah suatu daya dorong atau penggerak yang dapat menimbulkan aktivitas belajar, menjamin kelangsungan belajar, dan memberikan arah terhadap aktivitas belajar dalam rangka 
mencapai suatu tujuan belajar, yang dilatar belakangi oleh adanya kebutuhan akan prestasi belajar yang tinggi dan kebutuhan aktualisasi diri.

Motivasi belajar dalam hal ini merupakan motivasi instrinsik yang tumbuh dari dalam diri individu, mencakup delapan indikator, yaitu: durasi kegiatan; frekuensi kegiatan; persistensi pada kegiatan; ketabahan, keuletan dan kemampuan dalam mengahadapi rintangan dan kesulitan; devosi dan pengorbanan untuk mencapai tujuan; tingkat aspirasi yang hendak dicapai dengan kegiatan yang dilakukan; tingkat kualifikasi prestasi atau produk yang dicapai dari kegiatan yang dilakukan; dan arah sikap terhadap sasaran kegiatan.

\section{METODE PENELITIAN}

Metode penelitian yang digunakan dalam penelitian ini adalah metode survei dengan pendekatan korelasional. Penelitian survei korelasional berupaya menjelaskan ada tidaknya hubungan antarvariabel. Penelitian yang dilakukan dengan cara survei mengkaji populasi yang besar maupun kecil dengan menyeleksi serta mengkaji sampel yang dipilih dari populasi itu, untuk menemukan insidensi, distribusi, dan interelasi relatif dari variabel-variabel sosiologis dan psikologis (Kerlinger, 2005).

Penetapan jumlah sampel menurut pendapat Roscoe (dalam Sugiyono, 2007) bila dalam penelitian akan melakukan analisis dengan multivariance (korelasi atau regresi), maka jumlah anggota sampel minimal 10 kali dari jumlah variabel yang diteliti. Berdasarkan pendapat tersebut, maka dalam penelitian ini jumlah sampel ditentukan lebih dari batas minimal, yakni 15 kali dari jumlah variabel yang diteliti. Karena jumlah variabel dalam penelitian ini ada 4, maka jumlah anggota sampelnya sebanyak $15 \times 4=$ 60 orang. Selain alasan lebih dari batas minimal, peneliti berharap jumlah sampelnya mendekati $10 \%$ dari populasi. Teknik pengumpulan data dalam penelitian ini dengan dua cara. Teknik yang pertama dengan cara mengambil nilai tes/ulangan mata pelajaran Fisika kelas XI IPA SMA Negeri 1 Metro pada semester gasal tahun pelajaran 2009/2010 dari dokumentasi. Kedua memberikan angket tertutup berskala tiga, terhadap bimbingan guru. Dilakukan uji validitas dan reliabilitas terhadap instrumen penelitian. Hasil uji validitas dengan menggunakan korelasi Product Moment hasilnya dari 35 soal yang valid 30 soal ( $r$ hitung $\geq 0,444$ pada taraf signifikansi 5\%), nilai reliabilitasnya mengunakan rumus Alpha Cronbach. Untuk memudahkan perhitungannya, maka menggunakan program SPSS. Hasil dari perhitungan reliabilitas dengan menggunakan SPSS diperoleh nilai reliabilitas 0,949. Tingkat riliabilitasnya termasuk sangat kuat atau sangat tinggi.

\section{HASIL PENELITIAN DAN PEMBAHASAN}

\section{Hasil Penelitian}

Data hasil penelitian variabel bimbingan guru, dengan motivasi belajar berupa skor dari hasil angket tertutup yang diberikan anggota sampel. Sedangkan data prestasi belajar, diperoleh dari dokumen 
sekolah yang berupa nilai hasil ujian/ulangan mata pelajaran Fisika peserta didik kelas XI IPA SMA Negeri 1 Metro pada semester gasal Tahun pelajaran 2009/2010.

Berdasarkan data hasil penelitian dan hasil pengujian dari keempat hipotesis, ternyata hipotesis yang kesatu, dan kedua hanya dapat diterima pada hubungan positif dan signifikan. Keeratannya tidak erat, yakni termasuk kategori cukup erat, karena nilai koefisien korelasi $\mathrm{rx}_{1} \mathrm{y}$ dan $\mathrm{rx}_{2} \mathrm{y}$ berada pada kategori $0.40<r<0.599$. Sedangkan pada hipotesis ketiga dan keempat, baik secara sendiri maupun secara bersama-sama dapat diterima, yakni terdapat hubungan positif, erat dan signifikan antara variabel bebas dengan variabel terikat pada taraf signifikansi $1 \%$. Pembahasan masing-masing pengujian hipotesis diuraikan sebagai beikut.

\section{Pembahasan}

Berdasarkan pengujian hipotesis, temuan yang diperoleh ada hubungan positif, cukup erat dan signifikan antara bimbingan guru dan motivasi belajar dengan prestasi belajar. Temuan tersebut membuktikan bahwa semakin tinggi pemberian bimbingan guru kepada siswa dalam bidang belajar, dan semakin tinggi motivasi belajar siswa, maka akan semakin tinggi prestasi belajarnya. Fakta yang ditemukan bahwa prestasi belajar siswa meningkat, jika guru lebih intensif dalam memberikan bimbingan. Hal ini sesuai dengan jabatan guru sebagai tenaga pendidik profesional dengan tugas utama mendidik, mengajar, membimbing, mengarahkan, melatih, menilai, dan mengevaluasi peserta didik

Guru sebagai tenaga yang profesional dalam tugas membimbing siswa, khususnya dalam bimbingan belajar yang mencakup pengembangan motivasi, sikap dan kebiasaan belajar yang baik, mengembangkan keterampilan belajar yang baik. Sikap siswa terhadap bimbingan guru dan prestasi belajar yang diperoleh sangat dipengaruhi oleh kompetensi atau profesionalitas guru dalam menjalankan tugasnya. Guru sebagai individu dewasa memberikan bimbingan kepada siswa yang belum dewasa. Menyadari bahwa siaswa adalah individu yang belum dewasa, sehingga masih sangat membutuhkan bimbingan dari guru sebagai individu yang telah dewasa, agar mencapai kedewasaan dan perkembangan individu secara optimal.

Selain itu guru bertugas menumbuhkembangkan sikap dan kebiasaan belajar yang baik, artinya bahwa sikap dan kebiasaan belajar siswa dapat dipengaruhi oleh guru. Semakin intensif guru memberikan bimbingan/bantuan, arahan, dan semakin tinggi motivasi belajarnya, maka siswa akan memiliki sikap dan kebiasaan belajar yang baik. Peserta didik yang memiliki motivasi belajar yang lebih tinggi lebih baik, maka akan memiliki sikap dan kebiasaan belajar yang baik dan akan memiliki prestasi belajar yang lebih baik, dibandingkan dengan siswa yang motivasi belajarnya rendah (kurang baik), sikap maupun kebiasaan belajar yang kurang baik. Demikian bahwa semakin tinggi motivasi dalam diri siswa untuk belajar, maka semakin tinggi prestasi belajarnya. 
Hal ini dapat dipahami karena prestasi belajar adalah kemampuan yang dimiliki siswa dalam kegiatan belajar yang biasa ditunjukkan dengan nilai hasil tes atau ulangan yang diberikan oleh guru. Prestasi belajar siswa merupakan hasil kegiatan belajar yang tidak lepas dari campur tangan guru, baik dalam proses pembelajaran, maupun dalam kegiatan ekstrakurikuler. Dalam proses pembelajaran antara lain guru memberikan bimbingan kepada siswa bagaimana memahami dan menyelesaikan soal, terlebih jika materinya harus dilakukan dengan melalui percobaan. Prestasi belajar siswa juga dapat dipengaruhi oleh motivasi belajar yang diberikan oleh guru (motivasi extrinsik) dan motivasi belajar yang datang dalam diri siswa (motivasi intrinsik). Semakin entensif atau semakin tinggi motivasi belajar diberikan oleh guru dan semakin tinggi motivasi belajar yang dimiliki siswa akan semakin tinggi prestasi belajarnya. Penelitiannya hanya dilakukan di satu sekolah yakni di SMA Negeri 1 Metro, dengan demikian generalisasi dari hasil penelitian ini hanya dapat dilakukan pada populasi yang memiliki karakteristik yang serupa.

\section{KESIMPULAN, DAN SARAN}

\section{Kesimpulan}

Berdasarkan hasil pengolahan data, dapat disimpulkan bahwa prestasi belajar siswa dapat ditingkatkan melalui peningkatan bimbingan guru, dan motivasi belajar. Hal ini didasarkan pada temuan sebagai berikut.

a. Ada hubungan yang positif, cukup erat dan signifikan antara bimbingan guru dengan prestasi belajar Fisika kelas XI IPA SMA Negeri 1 Metro. Hasil analisis menunjukkan bahwa bimbingan guru dengan prestasi belajar pada taraf signifikansi $1 \%$, berkorelasi sebesar 0,568 .

b. Ada hubungan yang positif, erat dan signifikan antara motivasi belajar dengan prestasi belajar Fisika kelas XI IPA SMA Negeri 1 Metro. Hasil analisis menunjukkan bahwa motivasi belajar hubungannya erat dengan prestasi belajar pada taraf signifikansi $1 \%$, korelasinya sebesar 0.617

c. Ada hubungan yang positif, erat dan signifikan antara bimbingan guru, dan motivasi belajar secara bersama-sama dengan prestasi belajar Fisika kelas XI IPA SMA Negeri 1 Metro. Hasil analisis menunjukkan bimbingan guru, dan motivasi belajar secara bersama-sama hubungannya erat dengan prestasi belajar pada taraf signifikansi 1\%, dengan nilai korelasinya sebesar 0,647.

\section{Saran}

Berdasarkan hasil penelitian, pembahasan dan simpulan, maka ada beberapa saran yang disampakan.

a. Guru hendaknya lebih intensip dalam melakukan bimbingan belajar kepada siswa, agar siswa lebih menyadari akan pentingnya bimbingan guru dalam meningkatkan prestasi belajarnya. Bimbingan guru dapat berupa penjelasan materi pelajaran yang mudah dimengerti siswa, cara mengerjakan soal secara runtut, pengecekan tugas/PR dengan teliti, memberikan cara belajar yang baik, 
membuat catatan atau ringkasan, memberikan kesempatan kepada siswa untuk menanyakan sesuatu yang belum jelas dan memberikan jawaban yang dapat diterima atau memuaskan siswa.

b. Guru hendaknya dapat menumbuhkan dan mengembangkan motivasi belajar siswa. Dalam hal ini guru dapat menciptakan suasana yang nyaman, menyenangkan, dan harmonis dalam proses bimbingan belajar maupun dalam proses pembelajaran. Hendaknya guru dapat memberikan contohcontoh penyelesaian soal yang mudah dimengerti dan diterima siswa, menyampaikan informasi keberhasilan alumni dalam memasuki pendidikan di Perguruan Tinggi. Demikian halnya siswa, hendaknya mau berusaha untuk terus giat belajar dan bersemangat, ulet atau gigih untuk mencapai tujuan belajar yang diinginkan.

\section{DAFTAR PUSTAKA}

Ahmadi, A. (2004). Psikologi Balajar. Jakarta: Rineka Cipta.

Anderson, W.Lorin., dkk. (2001). A Taxonomy for Learning, Teaching and Assesing. A. Revision of bloom's Taxonomy of Educational Objective: Abridged Edition, New York Longman Inc.

Burhanudin. (1995). Profesi Keguruan. Malang: Penerbit IKIP Malang.

Dimyati \& Mudjiono. (2006). Belajar dan Pembelajaran. Jakarta: Rineka Cipta.

Departemen Pendidikan dan Kebudayaan. (1991). Kamus Besar Bahasa Indonesia. Jakarta:Balai Pustaka.

Faturrohman, Pupuh \& Sutikno, M. S. (2007). Strategi Belajar Mengajar. Bandung: Refika Aditama.

Kerlinger, F. N. (2005). Azas-Azas Penelitian behavioral. Terjemahan: Simatupang. Yogyakarta: Gajah Mada Universiti Press.

Makmun, A. S. (2003). Psikologi Pendidikan. Bandung: Remaja Rosda Karya.

Mulyasa, E. (2007). Standar Kompetensi dan Sertifikasi Guru. Bandung: Remaja Rosdakarya.

Prayitno, (2004). Dasar-dasar Bimbingan dan Konseling. Jakarta: Rineka Cipta.

Sidi, I. D. (2001). Menuju Masyarakat Belajar. Jakarta:Paramadina.

Sugiyono. (2005). Memahami Penelitian Kualitatif. Bandung: Alfabeta.

Suryabrata, S. (2006). Psikologi Pendidikan. Jakarta: Raja Grafindo

Sopah, D. (2000). Pengaruh Model Pembelajaran dan Motivasi Berprestasi Terhadap Hasil Belajar. Jakarta: Jurnal Pendidikan dan Kebudayaan. 22(5). 121-127.

Tohirin. 2007. Bimbingan dan Konseling di Sekolah dan Madrasah Berbasis Integrasi. Jakarta: Raja Grafindo Persada.

Trianto. 2007. Model-Model Pembelajaran Inovatif Berorientasi Komstruktivistik, Konsep, Landasan Teoritis-Praktis dan Implementasinya. Jakarta: Prestasi Pustaka. 
\begin{tabular}{l|l} 
Sukirman & 35
\end{tabular}

Uno, H. B. 2008. Teori Motivasi dan Pengukurannya. Jakarta: Bumi Aksara.

Walgito, B. 2007. Psikologi Kelompok. Yogyakarta: Andi.

Winkel, W. S. 2004. Psikologi Pengajaran. Jakarta: Gramedia.

Yamin, Martinis, Ansari, \& Bansu, I. (2008). Taktik Mengembangkan Kemampuan Individual Siswa. Jakarta: Gaung Persada Press.

Yusuf, S. (2005). Landasan Bimbingan dan Konseling. Bandung: PT. Remaja Rosda Karya. 